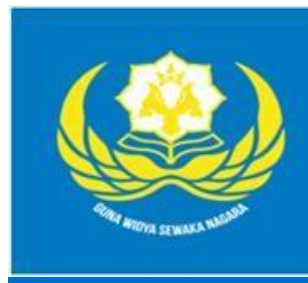

Linguistic Community Services Journal | Vol. 2, No. 2, 2021

P-ISSN: 2406-9019| E-ISSN: 2443-0668

Available online at

https://www.ejournal.warmadewa.ac.id/index.php/licosjournal

DOI: https://doi.org/10.22225/licosjournal.2.2.3135.38-45

\title{
KONSERVASI BAHASA BALI PADA KEGIATAN KESUBAKAN DI DESA MAMBAL
}

\author{
Mirsa Umiyati \\ Universitas Warmadewa, Denpasar, Bali-Indonesia \\ mirsa.umiyati@warmadewa.ac.id
}

\begin{abstract}
Abstrak
Seiring berjalannya waktu, penggunaan bahasa daerah mengalami perubahan secara signifikan dalam penggunaannya. Mengingat zaman yang terus berkembang, perubahan pola pikir dan gaya hidup yang menuntut adanya perbedaan dengan zaman yang sebelumnya. Saat ini penggunaan bahasa ibu atau bahasa Indonesia dan bahasa Inggris lebih diminati dalam pengaplikasiannya dikarenakan tuntutan zaman yang semakin maju. Dengan adanya fenomena seperti ini, penggunaan bahasa daerah pun secara perlahan kurang diminati khususnya generasi muda. Untuk mencegah hal itu terjadi maka dibutuhkan suatu solusi yaitu dengan memberikan pengajaran atau sosialisasi berupa konservasi dan revitalisasi bahasa daerah. Program pengabdian kepada masyarakat yang diselenggrakan oleh Universitas Warmadewa yang bertujuan untuk mengedukasi dan meningkatkan minat generasi muda terkait pelestarian bahasa Bali dalam kegiatan kesubakan, hal ini juga memiliki hubungan dengan aspek kebudayaan dan kebahasaan. Kegiatan ini dilakukan dengan metode kualitatif deskriptif yang mendeskripsikan fenomena nyata yang terjadi dalam suatu masyarakat. Data dikumpulkan dengan cara observasi, wawancara dan dokumentasi. Adapun sumber data yang digunakan yaitu data primer dan sekunder. Hasil dari pengabdian ini adalah generasi muda menunjukkan minat terhadap kegiatan kesubakan guna melanjutkan salah satu kebudayaan secara turun temurun yang telah di akui oleh dunia yaitu subak.
\end{abstract}

Kata Kunci : Bahasa Daerah; Konservasi; Revitalisasi.

\begin{abstract}
Over time, the use of regional languages has changed significantly in its use. Given the everevolving times, changing mindsets and lifestyles that demand differences from the previous era. Currently, the use of mother tongue or Indonesian and English is more desirable in its application due to the demands of an increasingly advanced era. With this phenomenon, the use of regional languages is slowly becoming less attractive, especially the younger generation. To prevent this from happening, a solution is needed, namely by providing teaching or socialization in the form of conservation and revitalization of local languages. The community service program organized by Warmadewa University which aims to educate and increase the interest of the younger generation regarding the preservation of the Balinese language in cultural activities, this also has a relationship with aspects of culture and language. This activity is carried out using descriptive qualitative methods that describe real phenomena that occur in a society. Data were collected by means of observation,
\end{abstract}


interviews and documentation. The data sources used are primary and secondary data. The result of this dedication is that the younger generation shows an interest in fertility activities in order to continue one of the hereditary cultures that has been recognized by the world, namely Subak.

Keywords: Local Languages; Conservation; Revitalization.

\section{PENDAHULUAN}

Bahasa memiliki arti penting dalam segala aspek kehidupan. Penggunaan bahasa menekankan pada cara berkomunikasi berupa tanda atau simbol, teks, maupun ujaran. Fungsi utama bahasa adalah sebagai media untuk berinteraksi dengan menyalurkan pemikiran, akal atau gagasan. Bahasa digunakan oleh masyarakat hal ini dapat dijumpai ketika terjadinya fenomena interaksi dengan bertukar opini sebagai salah satu aktivitas manusia. Pada dasarnya bahasa merupakan suatu identitas yang mempresentasikan masyarakat berdasarkan dilingkungannya. Menurut Nirmalasari (2017) secara sosio-kultural, bahasa adalah komponen kebudayaan yang ada secara nyata dan secara langsung juga dapat membedakan antara komunitas etnik yang satu dengan komunitas etnik yang lain. Sebagai realitas sosial, bahasa merupakan fenomena yang digunakan masyarakat penuturnya untuk berkomunikasi dan berinteraksi dalam konteks situasi dan konteks kultural dalam suatu lingkungan. Kekuatan dan persatuan masyarakat juga dapat terealisasikan dengan bahasa, sesuai dengan sumpah pemuda ayat ketiga yang menjabarkan bahwa bahasa adalah alat pemersatu bangsa.

Indonesia terdiri dari ribuan pulau yang dimana setiap pulaunya terdapat ragam bahasa daerah yang berbeda-beda. Bahasa daerah patut dilestarikan untuk memberdayakan budaya yang telah ada. Di era globalisasi saat ini fenomena kepunahan bahasa daerah telah menjadi permasalahan yang cukup serius, kemajuan teknologi dan perubahan pola dalam lingkungan menuntut masyarakat untuk menggunakan bahasa nasional maupun bahasa asing, sebab hal ini mempengaruhi segala aspek termasuk ekonomi, politik, sosial maupun budaya. Selain itu adanya kesenjangan sosial dikarenakan paradigma yang hadir diantara penutur bahasa daerah, nasional maupun bahasa asing. Namun dibalik itu, terdapat juga sisi negatif dengan berkembangnya teknologi terutama bagi kalangan muda yaitu terbawa arus globalisasi yang bisa mengakibatkan adanya perubahan ataupun akulturasi kebudayaan yang dominan terutama bahasa. Dalam hal ini, bahwa penggunaan bahasa Inggris sebagai alat komunikasi yang telah diterima secara global turut berperan pula dalam proses kepunahan bahasa daerah. Bahasa Inggris telah menjadi bahasa pergaulan internasional dan bahasa ilmu pengetahuan. Kebanyakan buku-buku dalam spektrum ilmu yang beragam saat ini ditulis dalam bahasa Inggris. Itu berarti seseorang dituntut untuk menguasai bahasa tersebut apabila ia ingin memasuki lingkungan pergaulan dunia yang penuh persaingan dengan sukses. Hal ini secara perlahan dapat mempengaruhi persentase pemakaian bahasa daerah seorang penutur menjadi lebih kecil karena bergeser pada pemakaian bahasa Inggris yang persentase pemakaiannya menjadi semakin besar (Tondo, 2009).

Menurut Widianto (2018) Paradigma masyarakat abad 21 menilai bahwa bahasa asing memiliki prestise lebih tinggi dibandingkan bahasa nasional dan bahasa daerah. Dengan kata lain, bahasa daerah berada di prioritas ketiga dalam penggunaannya setelah bahasa nasional dan bahasa asing. Masyarakat lebih memilih menggunakan bahasa nasional dan bahasa asing dalam berkomunikasi. Penutur bahasa asing juga dinilai lebih berpendidikan dan memiliki strata sosial lebih tinggi. Begitu pula sebaliknya, penutur bahasa daerah dinilai memiliki strata sosial di bawah penutur bahasa nasional dan bahasa asing. Maka perlu adanya rekonsiliasi dalam melestarikan bahasa daerah lebih tepatnya disebut dengan konservasi atau revitalisasi untuk mencegah kepunahan bahasa dengan target yaitu generasi muda. Lebih 
lanjut, tidak menutup kemungkinan dalam suatu daerah terdapat organisasi atau perkumpulan kelompok misalnya seperti subak yang menggunakan bahasa daerah untuk bersosialisasi dan bertukar pikiran dalam ranah kegiatan subak di Bali. Saat ini Bali mengalami perubahan sosial maupun ekonomi yang pesat, terdapat banyak situs atau warisan dunia salah satunya yaitu subak yang telah diakui oleh UNESCO (Salamanca et al., 2015).

Menurut Jha \& Schoenfelder (2011) Subak dikenal dalam antropologi sosial sebagai asosiasi pengairan yang menggabungkan ritual dan manajemen sumber daya, sedangkan menurut Roth (2011) sebagai suatu sistem, subak secara luas dikenal sebagai pengelolaan irigasi 'tradisional' lembaga budidaya padi di pulau Bali, Indonesia. Secara garis besar, subak merupakan suatu manajemen perairan yang dalam kegiatannya terdapat ritual serta peraturan (awig-awig).

Pada umumnya Tri Hita Karana adalah pedoman hidup untuk menuju kehidupan yang bahagia yang menjelaskanrelasi antar sesama yaitu harmoni antara manusia dengan Tuhan (parhyangan), harmoni antara manusia dengan sesamanya (pawongan), dan harmoni antara manusia dengan alam lingkungannya (palemahan) (Windia et al., 2015). Subak merupakan manifestasi dari Tri Hita Karana juga sebuah organisasi yang dimiliki oleh suatu masyarakat yang dipimpin oleh pekaseh yang mengatur sistem pengairan atau irigasi sawah. Sedangkan Yekti, (2017) Irigasi subak Bali dikenal sebagai pertemuan organisasi petani dengan tekad dan semangat yang tinggi untuk bekerja sama (gotong royong) dalam upaya memperoleh air untuk menghasilkan tanaman pangan, terutama padi dan palawija. adapun pengertian lain mengenai subak yaitu sebagai lembaga pengairan petani tradisional, kegiatan budidaya padi sudah ada di Bali sejak 882 .

Indonesia adalah negara agraris yang dimana terdapat banyak kekayaan alam yang melimpah, salah satu contohnya yaitu dalam sektor pertanian berupa kegiatan kesubakan. Namun saat ini minat dan perhatian generasi muda akan kegiatan tersebut lambat laun hilang, hal ini akan berdampak pada eksistensi subak, kebudayaan, dan bahkan dari segi bahasa. Apabila hal ini terjadi maka masyarakat tidak mengetahui makna dari bahasa yang digunakan dalam kegiatan kesubakan. Maka dalam hal ini, Universitas Warmadewa melakukan kegiatan Pengabdian Kepada Masyarakat (PKM) untuk meningkatkan minat dan partisipasi masyarakat di Desa Mambal, Kecamatan Abiansemal, Kabupaten Badung khususnya generasi muda yang akan melanjutkan pelestarian kegiatan kesubakan.

Pada Pengabdian Kepada Masyarakat kali ini terdapat dua bidang permasalahan yang dihadapi oleh Desa Mambal, Kecamatan Badung yaitu terbagi dua menjadi mikro dan makro. Masalah makro yaitu kurangnya bahan ajar berupa buku terkait kegiatan kesubakan dan minimnya pelatihan tentang pelaksanaan kegiatan kesubakan, adapun permasalahan mikro yaitu minimnya kesadaran generasi muda untuk berpartisipasi dalam kegiatan kesubakan dan kurangnya perhatian pemerintah setempat tentang pelaksanaan sosialisasi konservasi bahasa Bali dalam kegiatan persubakan.

Berdasarkan permasalahan yang telah dikemukakan, maka kegiatan Pengabdian Kepada Masyarakat (PKM) ini diselenggarakan untuk meningkatkan pengetahuan serta minat generasi muda pada kegiatan kesubakan agar dapat melestarikan bahasa daerah terkait subak dengan menggunakan strategi yaitu pendekatan berupa sosialisasi dan pelatihan mengenai pentingnya konservasi bahasa Bali terkait kegiatan kesubakan yang targetnya yaitu generasi muda di Desa Mambal, Kelurahan Abiansemal, Kecamatan Badung.

\section{METODE PENELITIAN}

Pada kegiatan Pengabdian Kepada Masyarakat (PKM) ini dilaksanakan dengan melalui tiga tahapan yang diantaranya adalah survey lokasi untuk mengetahui permasalahan yang dihadapi oleh calon mitra yang berada di Desa Mambal, Kecamatan Abiansemal, Kabupaten Badung yang targetnya yaitu generasi muda yang menghadapi permasalahan-permasalahan di 
era globalisasi salah satunya yaitu mengenai kebahasaan khusunya bahasa daerah terkait kegiatan kesubakan, setelah mengetahui kendala-kendala yang dihadapi maka selanjutnya terjadi kesepakatan kemitraan oleh kedua belah pihak, langkah terakhir yaitu merancang solusi-solusi yang akan di jalankan untuk meminimalisir atau bahkan memecahkan permasalahan yang dihadapi oleh mitra yaitu dengan memberikan pengajaran konservasi bahasa daerah mengenai kegiatan kesubakan. Apabila rancangan program telah disetujui dan disepakati maka kegiatan dapat Pengabdian Kepada Masyarakat dapat dijalankan.

Kegiatan ini diselenggarakan dengan melakukan pendekatan berupa metode kualitatif deskriptif dengan tujuan menjabarkan fenomena-fenomena yang terjadi dalam suatu masyarakat secara sistematis dan faktual berdasarkan data yang ada sehingga ciri, karakter, model yang ada dimasyarakat dapat diketahui.

\section{HASIL DAN PEMBAHASAN Pelaksanaan Kegiatan Pengabdian Kepada Masyarakat}

Pelaksanaan kegiatan Pengabdian Kepada Masyarakat dengan pendekatan berupa sosialisasi mengenai konservasi bahasa Bali dalam kegiatan kesubakan yang bertempat di Desa Mambal, Kecamatan Abiansemal, Kabupaten Badung dilakukan dengan tiga tahap. Yang pertama adalah observasi lapangan, sosialisasi dan penyusunan proposal kegiatan. Subak mambal terbagi atas 5 munduk yang menanam tanaman pangan yang beraneka ragam berupa, palawija, dan hortikultura. Komuditinya antara lain: Padi, Jagung manis, kacang tanah, kedelai, cabai besar, cabai rawit, mentimun, terong, kacang panjang, bunga pacar air, dan bunga gumitir (Dewi et al., 2017). Hal pertama yang dilakukan dalam tahap persiapan kegiatan PKM dengan pendekatan sosialisasi konservasi Bahasa Bali terkait kegiatan kesubakan adalah melakukan obervasi lapangan. Hal ini bermaksud untuk mengetajui permasalahan atau kendala maupun kebutuhan yang dihadapi oleh mitra. Kegiatan observasi lapangan dilakukan tampak seperti pada foto berikut ini.
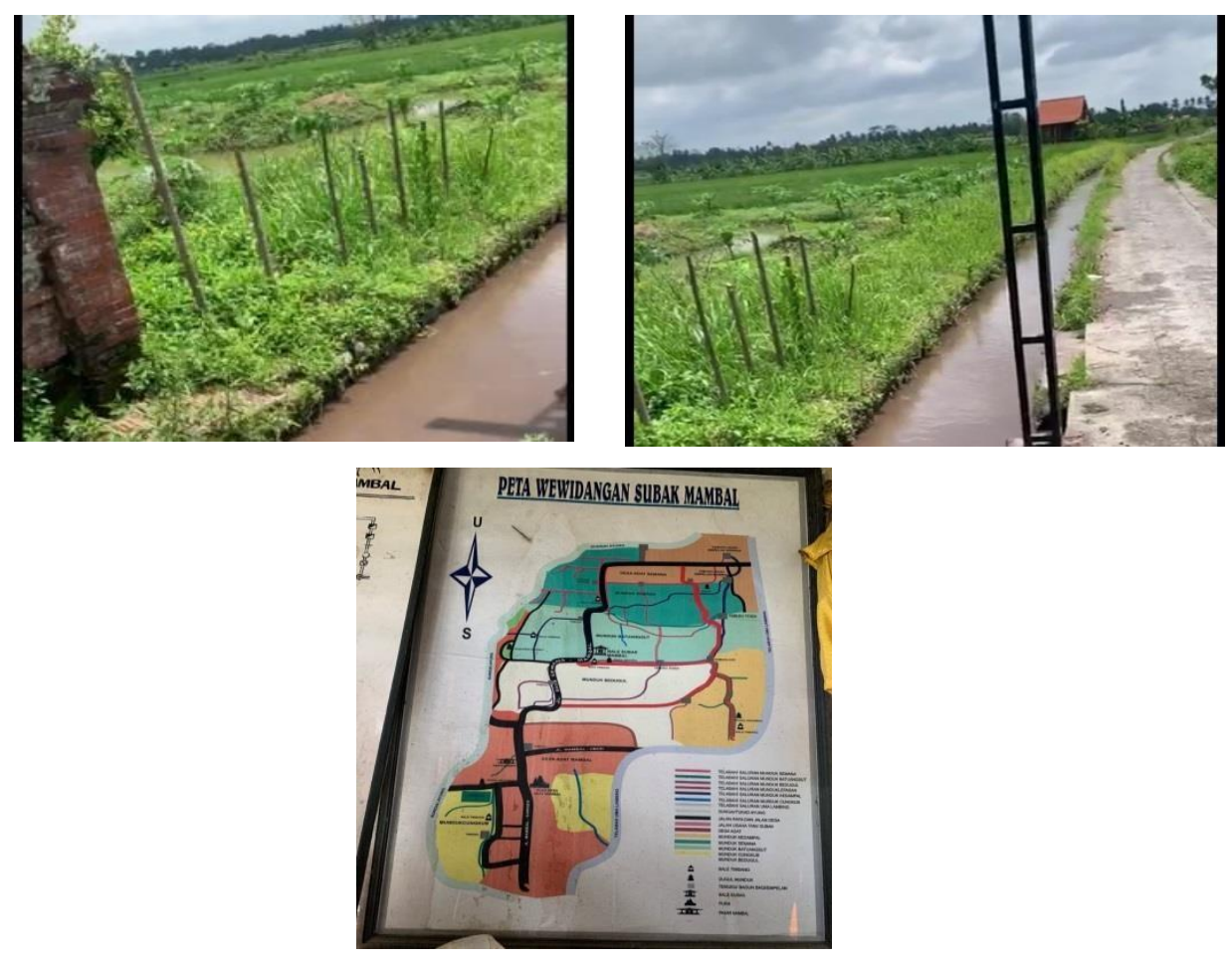

Gambar 1. Lokasi Subak Mambal 
Hasil yang didapatkan ketika berlangsungnya observasi lapangan yaitu, kurangnya perhatian dalam menyelenggarakan sosialisasi mengenai konservasi bahasa Bali dalam kegiatan kesubakan dan minimnya kesadaran akan pentingnya partisipasi dalam kegiatan kesubakan. Tahap selanjutnya yaitu melakukan sosialisasi dan rancangan program yang akan dilaksanakan yaitu berupa pengajaran konservasi bahasa Bali terkait kesubakan kepada masyarakat khususnya generasi muda. Observasi terdiri dari beberapa proses sesuai dengan kebutuhan penelitian. Proses observasi bergerak melalui rangkaian aktivitas bervariasi, dan selalu disesuaikan dengan kebutuhan dan situasionalnya. observasi untuk tujuan empiris mempunyai tujuan bermacam-macam. Observasi juga memiliki fungsi bervariasi. Tujuan dari observasi berupa deskripsi, melahirkan teori dan hipotesis (pada penelitian kualitatif), atau menguji teori dan hipotesis (pada penelitian kuantitatif) (Hasanah, 2016).
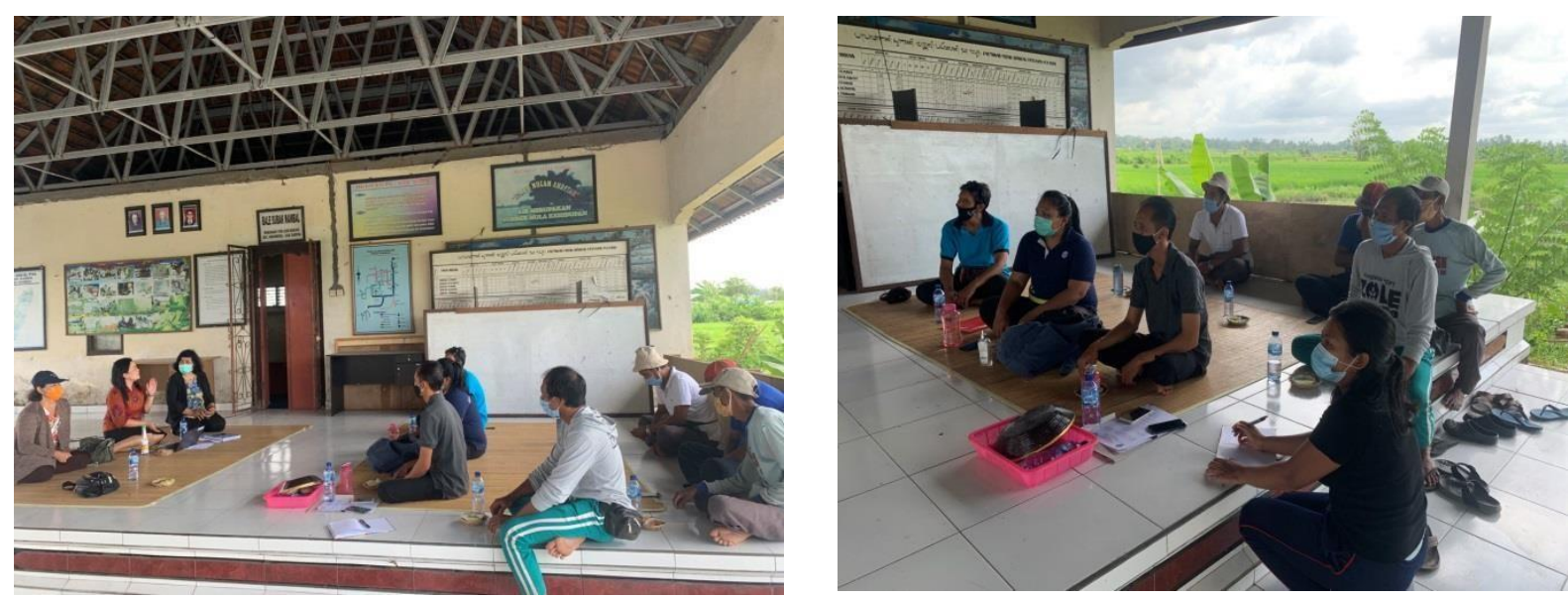

Gambar 2. Sosialisasi mengenai konservasi bahasa Bali terkait kesubakan

Pada tahap ini, terjadi sosialisasi antara kedua pihak yaitu Universitas Warmadewa dan Masyarakat Desa Mambal. Tujuannya adalah untuk mengetahui kendala yang dihadapi oleh mitra dan merumuskan atau merancang solusi untuk meminimalisir permasalahan yang ada. Pada umumnya, sosialisasi merupakan pendekatan yang tepat untuk mengetahui permasalahan ataupun kendala yang dihadapi oleh mitra, sebab pendekatan ini tidak bersifat sepihak. Terjadinya sosialisasi antara kedua pihak memiliki dampak yang sangat besar untuk menemukan solusi dari setiap permasalahan. Sosialisasi memiliki definisi yang sangat luas, bukan hanya bertukar opini dan merumuskan suatu hal yang akan dilaksanakan namun juga merupakan proses untuk mengetahui dan mempelajari budaya dan kebiasaan yang didalamnya terdapat aturan atau norma yang berlaku dalam masyarakat.

Menurut Nugroho (2018) sosialisasi adalah suatu proses belajar yang seseorang menghayati (internalisasi) norma-norma sosial di mana ia hidup sehingga menjadi individu yang baik. Sosialisasi adalah suatu proses mempelajari kebiasaan dan tata kelakukan untuk menjadi bagian dari suatu masyarakat. Dalam pengertian lain, sosialisasi diartikan sebagai proses membimbing individu ke dunia sosial. Dalam proses sosialisasi individu belajar tingkah laku, kebiasaan serta pola-pola kebudayaan lainnya, juga keterampilan-keterampilan sosial seperti berbahasa, bergaul, berpakaian, dll. Sosialisasi terjadi melalui proses pelaziman (conditioning) oleh lingkungan yang menyebabkan individu mempelajari pola kebudayaan yang fundamental seperti berbahasa, sopan santun, mengembangkan sikap yang dianut dalam masyarakat seperti sikap terhadap agama, dan segala sesuatu yang perlu bagi warga masyarakat yang baik. Dengan proses sosialisasi individu berkembang menjadi suatu pribadi 
atau makhluk sosial. Hal ini merupakan kesatuan integral dan sifat individu yang berkembang melalui proses sosialisasi.

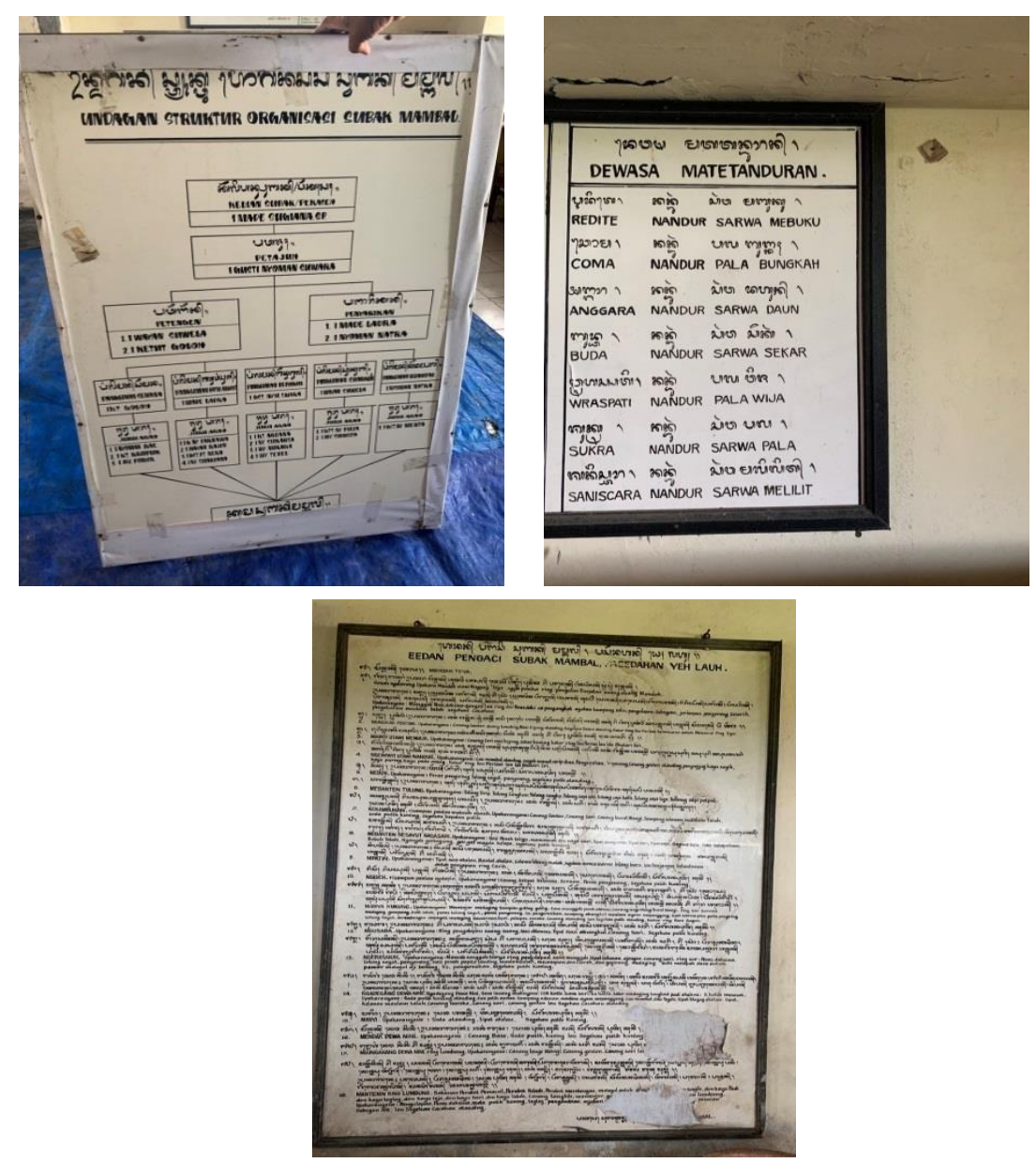

Gambar 3. Bahasa Bali mengenai kesubakan

Seiring berkembangnya arus globalisasi yang berdampak pada masyarakat baik secara internal maupun eksternal dengan dinamika perubahan yang makin pesat. Hal ini juga dapat berpengaruh besar terhadap kebahasaan dan kebudayaan daerah Bali. Dapat dikatakan bahwa sebagian besar masyarakat khusunya generasi muda lebih cepat terpengaruh trend globalisasi yang dapat mengakibatkan pada hilangnya minat atau pengetahuan mengenai bahasa daerah maupun kebudayaan yang saat ini mengalami krisis identitas dan hal ini merupakan kekhawatiran besar bagi masyarakat Bali. Menurut Giri (2017) Kekhawatiran tersebut memang didasarkan pada fenomena yang berkembang dilapangan bahwa bahasa Bali semakin ditinggalkan. Kedudukan bahasa Bali sebagai bahasa Ibu sudah tergeser oleh bahasa Indonesia. Penggunaannya juga mengalami penurunan, baik secara kualitas maupun kuantitas. Demikian juga dengan aksara Bali, keberadaannya memerlukan perhatian yang serius. Bahasa daerah memiliki fungsi yang terbatas, seperti (1) alat komunikasi intraetnis, (2) sarana menunjukkan keakraban, (3) sarana menunjukkan identitas daerah dan kebanggaan daerah. (Mustika, 2018)

Maka dengan adanya permasalahan yang telah diuraikan diatas, langkah selanjutnya yaitu melalukan konservasi atau revitalisasi bahasa daerah terkait kegiatan kesubakan. Fakta bahwa generasi muda secara perlahan kurang meminati kegiatan kebudayaan yaitu subak dan hal ini juga akan berdampak pada hilangnya pengetahuan mengetahui bahasa Bali terkait kegiatan kesubakan. Revitalisasi bahasa merupakan upaya dalam mengembalikan bahasa 
yang terancam punah setelah mengalami penurunan penggunaan atau berkurangnya jumlah penutur. Lebih lanjut, terdapat dua tugas utama dalam merevitalisasi bahasa yaitu 1) mengajarkan bahasa tersebut kepada orang lain yang belum mengetahui terkait bahasa tersebut. 2) bagi yang telah memepelajari dan memahami bahasa tersebut, maka diaplikasikan diberbagai situasi.

Jika diamati dalam konteks kebahasaan, revitalisasi bahasa yaitu menghidupkan atau menggiatkan kembali bahasa yang akan atau telah mati. Maka dalam hal ini program pegabdian kepada masyarakat yang diselenggarakan oleh Universitas Warmadewa berupaya menarik minat generasi muda untuk turut andil dalam kegiatan kesubakan agar mengetahui bahasa, makna serta filosofi terkait kesubakan khususnya mengenai kebahasaan, sebab apabila generasi muda merasa acuh maka secara tidak langsung juga akan berdampak pada hilangnya budaya yang telah turun-menurun dijalankan.

\section{SIMPULAN DAN SARAN}

Program Pengabdian Kepada Masyarakat (PKM) yang diselenggarakan oleh Universitas Warmadewa dan masyarakat di Desa Mambal menunjukkan bahwa hasil dari kegiatan ini meningkatkan minat generasi muda terkait dengan kegiatan kesubakan. Salah satu strategi untuk meningkatkan kemampuan berbahasa daerah terkait kesubakan dengan melakukan pendekatan berupa sosialisasi dan pengajaran bahasa daerah maka solusi yang tepat untuk meminimalisir atau bahkan memecahkan persoalan yang dihadapi oleh masyarakat di Desa Mambal yaitu mengenai konservasi dan revitalisasi bahasa Bali. Terkait hasil penelitian ini adapun saran yang dari peneliti yaitu pelatihan pengajaran bahasa daerah khususnya terkait kesubakan harus dilakukan secara berkelanjutan guna untuk melestarikan bahasa lokal.

\section{DAFTAR PUSTAKA}

Dewi, N. L. A. N. S., Tamba, I. M., \& Lestari, P. F. K. (2017). Kinerja Usaha Tani Padi Sawah (Kasus Subak Mambal, Kecamatan Abian Semal). Agrimeta, 7(13), 87-93.

Giri, I. M. A. (2017). Pelestarian Bahasa, Aksara, dan Sastra Bali Melalui Pengoptimalan Tripusat Pendidikan. Purwadita, 1(1), 27-32.

Hasanah, H. (2016). Teknik-Teknik Observasi (Sebuah Alternatif Metode Pengumpulan Data Kualitatif Ilmu-ilmu Sosial). At-Taqaddum, 8(1), 21.

Jha, N., \& Schoenfelder, J. W. (2011). Studies of the Subak: New Directions, New Challenges. Human Ecology, 39(1), 3-10.

Mustika, I. K. (2018). Pergeseran Bahasa Bali sebagai Bahasa Ibu di Era Global (Kajian Pemertahanan Bahasa). Purwadita, 2(1), 94-102.

Nirmalasari. (2017). Ekoleksikon Ke-Kaghati-An Bahasa Muna. RETORIKA: Jurnal Ilmu Bahasa, 2(2), 328-349.

Nugroho, P. (2018). Tripusat Pendidikan sebagai Basis Sosialisasi dan Pembentukan Karakter Siswa. Ijtimaiya: Journal of Social Science Teaching Volume, 2(1), 16891699.

Roth, D. (2011). The Subak in Diaspora: Balinese Farmers and the Subak in South Sulawesi. Human Ecology, 39(1), 55-68.

Salamanca, A. M., Nugroho, A., Osbeck, M., Bharwani, S., \& Dwisasanti, N. (2015). Managing a Living Cultural Landscape : Lessons and Insights from the Subaks of Bali , a UNESCO World Heritage Site. In Stockholm Environment Insitute. Stockholm Environment Institute.

Tondo, F. H. (2009). Kepunahan Bahasa-Bahasa Daerah: Faktor Penyebab dan Implikasi Etnolinguistis. Jurnal Masyarakat \& Budaya, 1(2), 277-296.

Widianto, E. (2018). Pemertahanan Bahasa Daerah melalui Pembelajaran dan Kegiatan di 
Vol. 2, No. 2 - Agustus 2021 Hal. 38-45

Sekolah. Jurnal Kredo, 1(2), 1-13.

Windia, W., Sumiyati, S., \& Sedana, G. (2015). Aspek Ritual pada Sistem Irigasi Subak sebagai Warisan Budaya Dunia. Jurnal Kajian Bali (Journal of Bali Studies), 5(1), 2356.

Yekti, M. I. (2017). Role of Reservoir Operation in Sustainable Water Supply to Subak Irrigation Schemes in Yeh Ho River Basin. In Taylor \& Francis Group. 